Article

\title{
Flux Growth and Crystal Structure Refinement of Calcite Type Borate $\mathrm{GaBO}_{3}$
}

\author{
Shichao Wang ${ }^{1}$, Ning Ye ${ }^{2}$ and Kenneth R. Poeppelmeier ${ }^{1, *}$ \\ 1 Department of Chemistry, Northwestern University, 2145 Sheridan Road, Evanston, IL 60208, \\ USA; E-Mail: shichao-wang@northwestern.edu \\ 2 Fujian Institute of Research on the Structure of Matter, Chinese Academy of Sciences, \\ 155 West Yangqiao Road, Fuzhou 350002, China; E-Mail: nye@fjirsm.ac.cn \\ * Author to whom correspondence should be addressed; E-Mail: krp@northwestern.edu; \\ Tel.: +1-847-491-3505; Fax: +1-847-491-7713.
}

Academic Editor: Glen Deacon

Received: 1 May 2015 / Accepted: 21 May 2015 / Published: 27 May 2015

\begin{abstract}
A single crystal of gallium borate, $\mathrm{GaBO}_{3}, 4 \times 4 \times 0.2 \mathrm{~mm}^{3}$ in size has been grown by spontaneous crystallization with a molten flux based on a $\mathrm{Bi}_{2} \mathrm{O}_{3}-3 \mathrm{~B}_{2} \mathrm{O}_{3}$ solvent. From single crystal X-ray diffraction measurement, $\mathrm{GaBO}_{3}$ was found to crystallize in the trigonal calcite type, space group $R-3 \mathrm{c}$, with cell dimensions $a=4.56590(10)$ and $c=14.1764(4) \AA$, $Z=6$. Layers of distorted $\left[\mathrm{GaO}_{6}\right]$ octahedra are interleaved by layers of triangular planar $\left[\mathrm{BO}_{3}\right]$ unites. The transmission spectrum on a single crystal indicated that the band gap of $\mathrm{GaBO}_{3}$ is $3.62 \mathrm{eV}$.
\end{abstract}

Keywords: borates; gallium borate; calcite type; crystal growth; flux

\section{Introduction}

Calcium carbonate, $\mathrm{CaCO}_{3}$, exists in three different polymorphs: The calcite, vaterite, and aragonite structures [1]. Triangle planar $\mathrm{BO}_{3}{ }^{3-}$ groups can replace $\mathrm{CO}_{3}{ }^{2-}$ to form metal orthoborates with the nominal formula $\mathrm{A}^{\mathrm{III}} \mathrm{BO}_{3}$ which have been determined to be isostructural with different forms of $\mathrm{CaCO}_{3}$. Usually, small cations of $\mathrm{A}^{3+}$ lead to the crystallization of $\mathrm{A}^{\mathrm{III}} \mathrm{BO}_{3}$ in a calcite type structure which belongs to the trigonal space group $R-3 c$. The $\mathrm{A}^{3+}$ caions occupy octahedral positions and can be substituted by $\mathrm{Al}^{3+}, \mathrm{In}^{3+}, \mathrm{Fe}^{3+}$ and $\mathrm{Sc}^{3+}$ [2-6]. These compounds have attracted attention because of their 
potential applications as photoluminescence materials, laser media, scintillating materials and magnetic materials $[7,8]$.

Gallium borate, $\mathrm{GaBO}_{3}$, has been well studied with respect to luminescence properties [9-11], thermal behavior $[12,13]$ and thermochemistry $[14,15]$ in phase equilibria in the $\mathrm{Ga}_{2} \mathrm{O}_{3}-\mathrm{B}_{2} \mathrm{O}_{3}$ system. Gallium borate melts incongruently, decomposes to $\beta-\mathrm{Ga}_{2} \mathrm{O}_{3}$ above $918{ }^{\circ} \mathrm{C}$, and crystallizes in the calcite-type structure with the unit cell $a=4.568 \AA$ and $c=14.182 \AA$ by powder X-ray diffraction [16]. Single crystal of calcite-type borates usually are grown by the hydrothermal method [4], high pressure solid state reaction [16] or in a flux. The $\mathrm{B}_{2} \mathrm{O}_{3}$ [13], $\mathrm{Li}_{2} \mathrm{O}_{-} \mathrm{B}_{2} \mathrm{O}_{3}[5,6], \mathrm{B}_{2} \mathrm{O}_{3}-\mathrm{PbO}-\mathrm{PbF}_{2}$ [17] systems have been proved to be suitable flux for growing calcite-type borates. Recently, Vitzthum et al. have also reported the structure of $\mathrm{GaBO}_{3}$ determined from crystals synthesized under high pressure [18]. We report a flux-based crystal growth procedure under ambient pressures to grow crystals up to $4 \times 4 \times 0.2 \mathrm{~mm}^{3}$ in size. In this contribution, the flux-based crystal growth procedure, crystal structure, and optical properties of $\mathrm{GaBO}_{3}$ are reported.

\section{Results and Discussion}

\subsection{Crystal Growth}

According to a previous study [12] of the thermochemistry of $\mathrm{GaBO}_{3}$ and phase equilibria in the $\mathrm{Ga}_{2} \mathrm{O}_{3}-\mathrm{B}_{2} \mathrm{O}_{3}$ system, the compound $\mathrm{GaBO}_{3}$ melts incongruently and decomposes to $\beta-\mathrm{Ga}_{2} \mathrm{O}_{3}$ above $918^{\circ} \mathrm{C}$. Thus, a flux must be used to grow single crystals. Here, transparent and light yellowish $\mathrm{GaBO}_{3}$ crystals have been grown by spontaneous crystallization in a molten flux based on the $\mathrm{Bi}_{2} \mathrm{O}_{3}-3 \mathrm{~B}_{2} \mathrm{O}_{3}$ solvent, which has a low melting temperature $\left(708{ }^{\circ} \mathrm{C}\right)$ [19] and good solubility for the calcite type borates [2]. There are two key experimental considerations in order to obtain phase pure $\mathrm{GaBO}_{3}$ : (1) The ratio of $\mathrm{GaBO}_{3}$ and $\mathrm{Bi}_{2} \mathrm{O}_{3}-3 \mathrm{~B}_{2} \mathrm{O}_{3}$; and (2) Annealing procedure. Without enough flux or annealing procedure, single crystals of $\beta-\mathrm{Ga}_{2} \mathrm{O}_{3}$ will be obtained as a secondary phase. Simultaneously, too much flux will lead to the formation of a glass because of the high viscosity of $\mathrm{B}_{2} \mathrm{O}_{3}$. As shown in Figure 1, the $\mathrm{GaBO}_{3}$ crystals have the typical morphology of the calcite type showing forms of well-formed hexagonal plates elongated along the $c$-axis, with sizes up to $4 \times 4 \times 0.2 \mathrm{~mm}^{3}$. They are chemically stable with respect to hot water and strong acid.

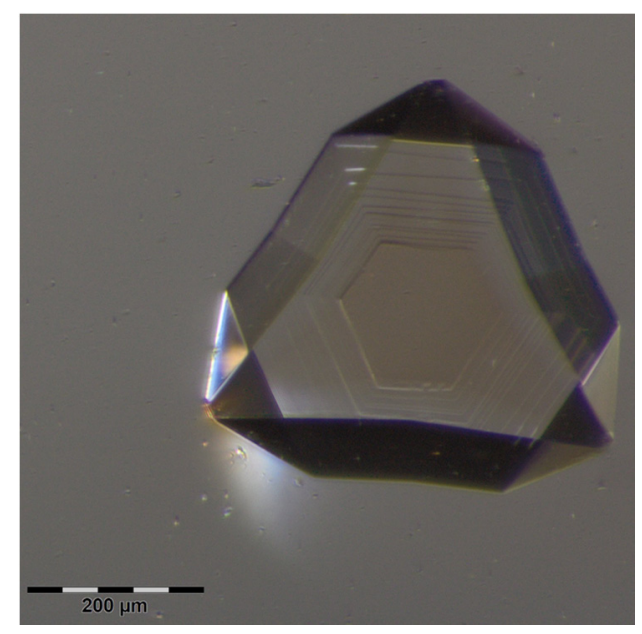

Figure 1. As-grown $\mathrm{GaBO}_{3}$ crystal. 


\subsection{Structural Analysis}

$\mathrm{GaBO}_{3}$ is isostructural with the mineral calcite $\mathrm{CaCO}_{3}$ and other calcite type borates, such as $\mathrm{AlBO}_{3}$, $\mathrm{InBO}_{3}, \mathrm{FeBO}_{3}$ and $\mathrm{ScBO}_{3}$. The cell dimensions of $\mathrm{GaBO}_{3}(a=4.56590(10)$ and $c=14.1764(4) \AA)$ are larger than $\mathrm{AlBO}_{3}(a=4.4638(3)$ and $c=13.745(1) \AA)[4]$ and smaller than $\operatorname{InBO}_{3}(a=4.8217(8)$ and $c=15.438(1) \AA$ ) [6]. The structure of $\mathrm{GaBO}_{3}$ is illustrated in Figure 2.

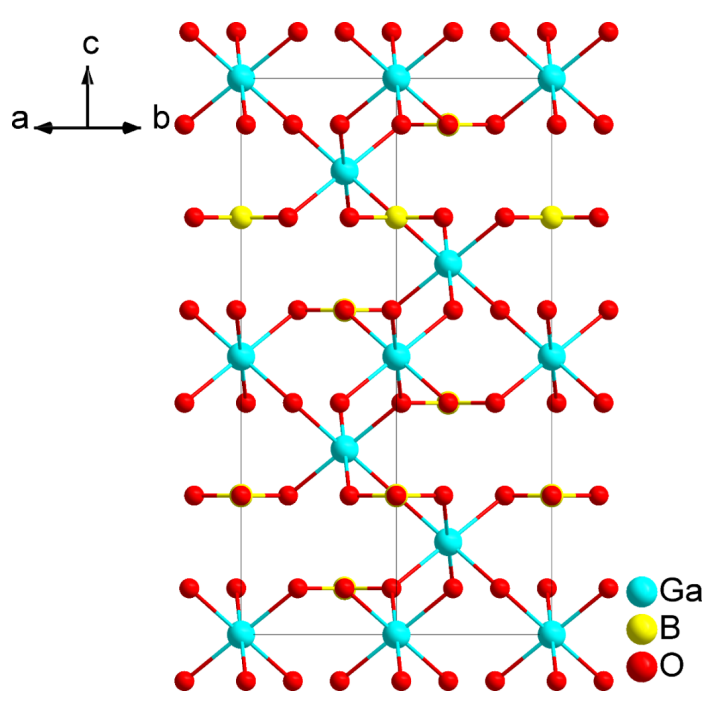

Figure 2. Crystal structure of $\mathrm{GaBO}_{3}$.

$\mathrm{GaBO}_{3}$ crystallizes in the centrosymmetric trigonal space group $R-3 c$. In the asymmetric unit of $\mathrm{GaBO}_{3}, \mathrm{Ga}, \mathrm{B}$, and $\mathrm{O}$ occupy only one crystallographically unique positions, respectively. The bond length and bond angles are listed in Table 1. It is worthwhile to note that our crystal structure (cell constants, bond distances and angles) agrees very closely with those reported by Vitzthum et al. [18].

Table 1. Bond lengths and bond angles for $\mathrm{GaBO}_{3}\left(\AA,^{\circ}\right)$

\begin{tabular}{cccc}
\hline \multicolumn{2}{c}{ Bond lengths $(\AA)$} & \multicolumn{2}{c}{ Bond angles $\left(^{\circ}\right)$} \\
\hline $\mathrm{Ga}-\mathrm{O}$ & $1.9875(2)$ & $\mathrm{O}-\mathrm{Ga}-\mathrm{O}$ & $180.00(3)$ \\
& & $\mathrm{O}-\mathrm{Ga}-\mathrm{O}$ & $91.718(7)$ \\
& $\mathrm{O}-\mathrm{Ga}-\mathrm{O}$ & $91.719(8)$ \\
& $\mathrm{B}-\mathrm{O}-\mathrm{Ga}$ & $117.055(14)$ \\
& & $\mathrm{O}-\mathrm{B}-\mathrm{O}$ & 120 \\
$\mathrm{~B}-\mathrm{O}$ & \multirow{2}{*}{$1.3789(5)$} & $\mathrm{O}-\mathrm{Ga}-\mathrm{O}$ & 180 \\
& & $\mathrm{O}-\mathrm{Ga}-\mathrm{O}$ & $88.282(7)$ \\
& $\mathrm{O}-\mathrm{Ga}-\mathrm{O}$ & $88.281(8)$ \\
& & $\mathrm{Ga}-\mathrm{O}-\mathrm{Ga}$ & $125.89(3)$ \\
\hline
\end{tabular}

The $\mathrm{B}$ atoms are coordinated to three $\mathrm{O}$ atoms to form planar $\left[\mathrm{BO}_{3}\right]$ triangles with $\mathrm{B}-\mathrm{O}$ bond lengths $1.3789(5) \AA$ and $\mathrm{O}-\mathrm{B}-\mathrm{O}$ bond angles $120^{\circ}$. The Ga atoms are bound to six $\mathrm{O}$ atoms to form distorted [GaO6] octahedra with $\mathrm{Ga}-\mathrm{O}$ bond lengths $1.9875(2) \AA$ and $\mathrm{O}-\mathrm{Ga}-\mathrm{O}$ bond angles from $88.281(8)^{\circ}$ to $180.00(3)^{\circ}$. Each $\mathrm{O}$ atom is threefold coordinated with two $\mathrm{Ga}$ atoms and one $\mathrm{B}$ atom. The compound adopts the classical calcite structure type with Ga-centered distorted octahedra connected by sharing vertices with the isolated $\left[\mathrm{BO}_{3}\right]$ triangles that extend parallel to the $a b$ plane. The $\left[\mathrm{BO}_{3}\right]$ borate groups 
are distributed in layers so that the $\left[\mathrm{BO}_{3}\right]$ triangles present reversed orientations in alternating layers, while each $\left[\mathrm{GaO}_{6}\right]$ octahedron share only vertices with other six [ $\left.\mathrm{GaO}_{6}\right]$ octahedra (Figure 3), three from the upper layer and three from the lower layer, resulting in the final 3D framework.

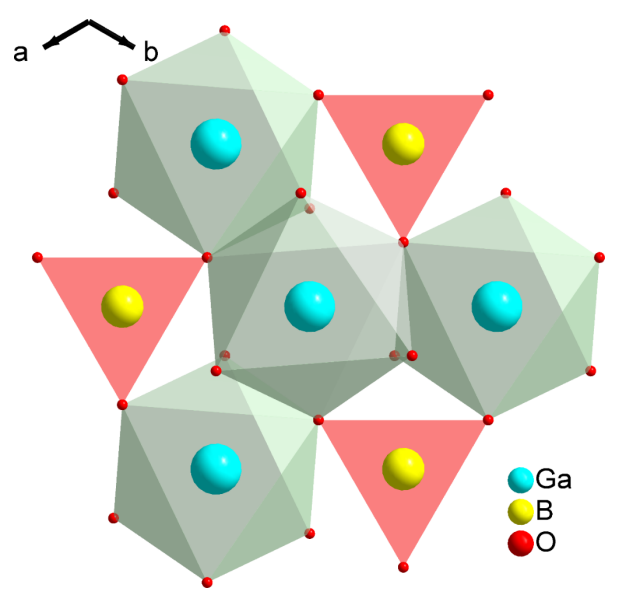

Figure 3. The connection of the polyhedra in the structure of $\mathrm{GaBO}_{3}$ shown along the $c$-axis.

As shown in Figure 4, the powder X-ray diffraction patterns of $\mathrm{GaBO}_{3}$, as-grown crystals and the theoretical simulations from single crystal structures match each other very well. The differences in peak intensity for the same crystallographic index between the two patterns are believed to be caused by the preferred orientation of the powder samples. The powder patterns also confirmed the presence of small amount of $\beta-\mathrm{Ga}_{2} \mathrm{O}_{3}$ as a secondary phase.

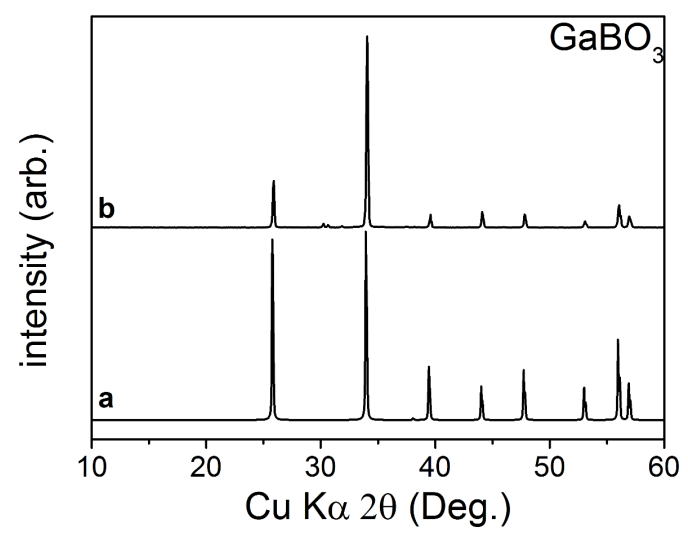

Figure 4. X-ray powder diffraction patterns of (a) simulation results, and (b) crystal sample.

The result of ICP elemental analysis of $\mathrm{GaBO}_{3}$ is calculated on the basis of one $\mathrm{B}$ atom and three $\mathrm{O}$ atoms in each formula unit. The result of $\mathrm{Ga}_{0.94} \mathrm{BO}_{3}$ is consistent with the compositions determined from the single crystal X-ray analysis.

\subsection{Optical Properties}

To confirm the band gap of $\mathrm{GaBO}_{3}$, transmittance $(T)$ and reflectance $(R)$ spectra were recorded from single crystals. From $T$ and $R$, the absorption coefficient $(\alpha)$ can be determined as a function of incident photon energy. As shown in Figure 5, a linear fit to $\alpha^{2}$ versus energy gives a band gap $3.62 \mathrm{eV}$ for $\mathrm{GaBO}_{3}$ crystal. 


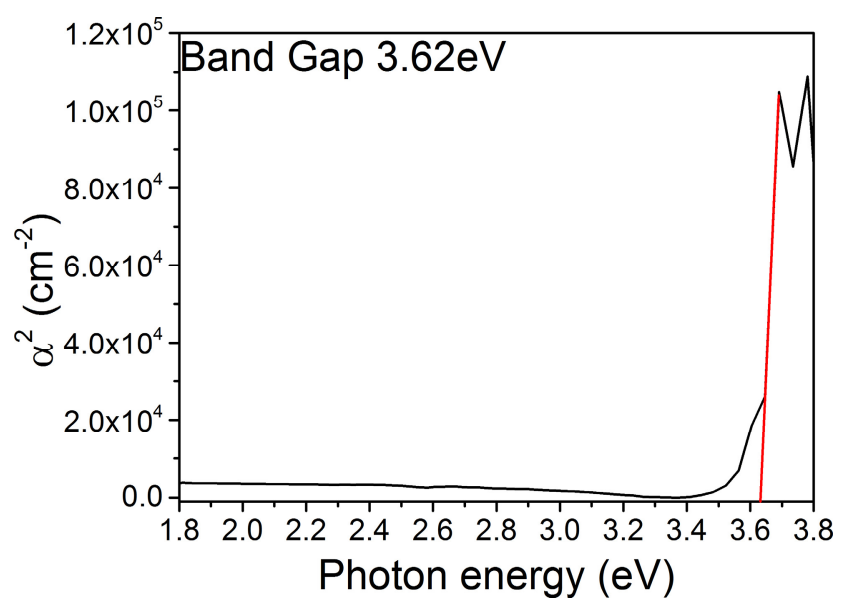

Figure 5. Square of absorption coefficient vs. photon energy of a $\mathrm{GaBO}_{3}$ sample. The optical band gap of the sample was estimated to be $3.62 \mathrm{eV}$.

\section{Experimental Section}

\subsection{Growth}

Single crystals of $\mathrm{GaBO}_{3}$ were grown from a high temperature solution by using $\mathrm{Bi}_{2} \mathrm{O}_{3}-3 \mathrm{~B}_{2} \mathrm{O}_{3}$ as a flux. This solution was prepared in a platinum crucible with an $\mathrm{Al}_{2} \mathrm{O}_{3}$ lid by melting a reagent-grade mixture of $\mathrm{Bi}_{2} \mathrm{O}_{3}$ (99.999\%, Alfa-Aesar, Ward Hill, MA, USA), $\mathrm{Ga}_{2} \mathrm{O}_{3}\left(99.99 \%\right.$, Alfa-Aesar) and $\mathrm{B}_{2} \mathrm{O}_{3}$ $\left(99.999 \%\right.$, Alfa-Aesar) in a molar ratio of $\mathrm{Ga}_{2} \mathrm{O}_{3}: \mathrm{Bi}_{2} \mathrm{O}_{3}: \mathrm{B}_{2} \mathrm{O}_{3}=3: 4: 15$. The mixture was heated in a programmable temperature electric furnace at $1000{ }^{\circ} \mathrm{C}$, and held for one day until the melt became transparent and clear. The homogenized melt solution was then cooled rapidly $\left(50^{\circ} \mathrm{C} / \mathrm{h}\right)$ to the initial temperature of crystallization $850{ }^{\circ} \mathrm{C}$, and then cooled slowly to the final crystallization temperature $700{ }^{\circ} \mathrm{C}$ at the rate of $3{ }^{\circ} \mathrm{C} / \mathrm{h}$. After annealing for three days at $700{ }^{\circ} \mathrm{C}$, the melt was allowed to cool to room temperature by turning off the power of the furnace. The flux attached to the crystal was readily dissolved in nitric acid and hot water.

\subsection{Elemental Analysis}

Elemental analysis of the crystals was performed using a Jobin Yvon Ultima2 inductively coupled plasma optical emission spectrometer (ICP-OES) with Sepex Certiprep standards. The crystal samples were dissolved in a mixture of nitric acid $(2 \mathrm{~mL})$, phosphoric acid $(3 \mathrm{~mL})$ and hydrochloric acid $(5 \mathrm{~mL})$ by microwave digestion at $220^{\circ} \mathrm{C}$ for $2 \mathrm{~h}$.

\subsection{X-ray Measurements}

X-ray diffraction patterns of polycrystalline materials were obtained on a Rigaku Ulitma powder $\mathrm{X}$-ray diffractometer (Rigaku Americas, Woodlands, TX, USA) by using $\mathrm{Cu} \mathrm{K \alpha}$ radiation $(\lambda=1.540598 \AA)$ at room temperature in the angular range of $2 \theta=5^{\circ}-65^{\circ}$ with a scan step width of $0.05^{\circ}$ and a dwell step of $2 \mathrm{~s}$.

Single crystal X-ray diffraction data were collected at $100 \mathrm{~K}$ on a Bruker Kappa APEX II CCD diffractometer (Bruker AXS Inc., Madison, WI, USA) with monochromatic Mo Ka radiation 
$(\lambda=0.71073 \AA)$. A transparent crystal block was mounted on a glass fiber with epoxy for structure determination. The data were integrated using the SAINT program (Bruker AXS Inc., Madison, WI, USA). Absorption corrections based on the Multi-scan technique were applied with SADABS (Bruker AXS Inc., Madison, WI, USA). The structure was solved by direct methods using SHELXS-97 [20] and then refined by full-matrix least-squares refinement on $F^{2}$ with SHELXL-97 [20] found in the software suite WinGX v2013.3 [21]. The structure was verified using ADDSYM algorithm from the program PLATON [22], and no higher symmetries were found. Relevant crystallographic data and details of the experimental conditions are summarized in Table 2. Atomic coordinates and isotropic displacement coefficients are listed in Table 3 . The Cif document could be found in supplementary information.

Table 2. Crystal data and structure refinement for $\mathrm{GaBO}_{3}$.

\begin{tabular}{|c|c|}
\hline Parameter & Data \\
\hline Formula mass (amu) & 128.53 \\
\hline Crystal system & Trigonal \\
\hline Space group & $R-3 c$ \\
\hline$a(\AA)$ & $4.56590(10)$ \\
\hline$c(\AA)$ & $14.1764(4)$ \\
\hline$V\left(\AA^{3}\right)$ & $255.946(11)$ \\
\hline Z & 6 \\
\hline Crystal size (mm) & $0.15 \times 0.11 \times 0.07$ \\
\hline$\rho($ calcd $)\left(\mathrm{g} / \mathrm{cm}^{3}\right)$ & 5.003 \\
\hline $\mathrm{F}(000)$ & 360 \\
\hline$\mu\left(\mathrm{mm}^{-1}\right)$ & 15.716 \\
\hline Absorption correction & Multi-scan \\
\hline Temperature (K) & $100(2)$ \\
\hline Wavelength $(\AA)$ & 0.71073 \\
\hline \multirow[t]{2}{*}{$\theta(\operatorname{deg})$} & $5.91-45.16$ \\
\hline & $-8 \leq h \leq 9$ \\
\hline \multirow[t]{2}{*}{ Index range } & $-8 \leq k \leq 9$ \\
\hline & $-26 \leq l \leq 28$ \\
\hline$R_{\text {int }}$ & 0.0353 \\
\hline Reflections collected & 6025 \\
\hline Independent reflections & 242 \\
\hline Reflections $(I>2 \sigma(I))$ & 237 \\
\hline Completeness & $100 \%$ \\
\hline Data/Restraints/Parameters & $242 / 0 / 11$ \\
\hline$R / w R(I>2 \sigma(I))$ & $0.0153 / 0.0432$ \\
\hline$R / w R$ (all data) & $0.0155 / 0.0433$ \\
\hline GOF on $F^{2}$ & 1.172 \\
\hline Largest diff. peak and hole $\left(\mathrm{e} / \AA^{-3}\right)$ & 1.504 and -1.156 \\
\hline
\end{tabular}


Table 3. Atomic positions and isotropic displacement factors for $\mathrm{GaBO}_{3}$.

\begin{tabular}{ccccccc}
\hline Atom & $\boldsymbol{x}$ & $\boldsymbol{y}$ & $\boldsymbol{z}$ & Wyckoff & $\boldsymbol{U}_{\text {eq }}\left(\AA^{2}\right)$ & Occupancy \\
\hline $\mathrm{Ga}$ & 0 & 0 & 0 & $6 \mathrm{~b}$ & $0.00262(8)$ & 1 \\
$\mathrm{~B}$ & 0 & 0 & $1 / 4$ & $6 \mathrm{a}$ & $0.0043(3)$ & 1 \\
$\mathrm{O}$ & $0.30201(12)$ & 0 & $1 / 4$ & $18 \mathrm{e}$ & $0.00391(11)$ & 1 \\
\hline
\end{tabular}

\subsection{Optical Measurements}

The optical transmission and reflection spectra of single crystal samples were measured with a PerkinElmer Lambda $1050 \mathrm{UV} /$ Vis/NIR spectrometer over the range of $180-860 \mathrm{~nm}$ with a photomultiplier tube (PMT). In the transmission configuration, the transmittance $T$, reflectivity $R$, and absorption coefficient $\alpha$ are related by the expression

$$
\alpha=\frac{1}{d} \ln \left[\frac{(1-R)^{2}}{2 T}+\sqrt{\frac{(1-R)^{4}}{4 T^{2}}+R^{2}}\right]
$$

where $d$ is the thickness of the sample $(d=0.2 \mathrm{~mm})$. The reflectivity was obtained by normalizing the reflectance of the sample to that of a silicon reference, which has a reflectivity of 0.3 at the wavelength regime $>1300 \mathrm{~nm}$. The band gap energy is determined by plotting the square of absorption coefficient, $\alpha^{2}$, versus photon energy. Extrapolating the linear part of the curve to zero and finding the point of interception with the $\mathrm{E}$ axis gives the corresponding band gap energy.

\section{Conclusions}

Transparent and yellowish calcite type borate $\mathrm{GaBO}_{3}$ crystals have been grown using $\mathrm{Bi}_{2} \mathrm{O}_{3}-\mathrm{B}_{2} \mathrm{O}_{3}$ as a flux by spontaneous crystallization for the first time. The crystal structure of $\mathrm{GaBO}_{3}$ is refined by single crystal X-ray diffraction. It crystallizes in space group $R$-3c with cell dimensions $a=4.56590(10)$ and $c=14.1764(4) \AA$. The transmission spectrum results indicated that band gap of $\mathrm{GaBO}_{3}$ compound is $3.62 \mathrm{eV}$.

\section{Acknowledgments}

This material is based upon work supported by National Science Foundation (Awards DMR-1005827 and DMR-1307698). We thank Zhifu Liu for helping with band gap measurement.

\section{Author Contributions}

Shichao Wang and Ning Ye conceived the project, Shichao Wang performed the experiments and analyzed the data under the direction of Ning Ye and Kenneth R. Poeppelmeier, and all authors contributed in the manuscript preparation.

\section{Conflicts of Interest}

The authors declare no conflict of interest. 


\section{References}

1. Levin, E.M.; Roth, R.S.; Martin, J.B. Polymorphism of $\mathrm{ABO}_{3}$ type rare earth borates. Am. Mineral. 1961, 46, 1030-1055.

2. Bernal, I.; Struck, C.W.; White, J.G. New transition metal borates with the calcite structure. Acta Crystallogr. 1963, 16, 849-850.

3. Diehl, R. Crystal structure refinement of ferric borate, FeBO3. Solid State Commun. 1975, 17, 743-745.

4. Vegas, A.; Cano, F.H.; Garciablanco, S. Refinement of aluminium orthoborate Sample: 30-50 degree reflections, $\mathrm{Al}^{3+}$, O- Note: Calcite structure type. Acta Crystallogr. Sect. B Struct. Sci. 1977, 33, 3607-3609.

5. Keszler, D.A.; Sun, H.X. Structure of $\mathrm{ScBO}_{3}$. Acta Crystallogr. Sect. C Cryst. Struct. Commun. 1988, 44, 1505-1057.

6. Cox, J.R.; Keszler, D.A. InBO3. Acta Crystallogr. Sect. C Cryst. Struct. Commun. 1994, 50, $1857-1859$.

7. Ding, X.X.; Huang, Z.X.; Huang, X.T.; Gan, Z.W.; Cheng, C.; Tang, C.; Qi, S.R. Synthesis of gallium borate nanowires. J. Cryst. Growth 2004, 263, 504-509.

8. Santamaria-Perez, D.; Gomis, O.; Sans, J.A.; Ortiz, H.M.; Vegas, A.; Errandonea, D.; Ruiz-Fuertes, J.; Martinez-Garcia, D.; Garcia-Domene, B.; Pereira, A.L.J.; et al. Compressibility systematics of calcite-type borates: An experimental and theoretical structural study on $\mathrm{ABO}_{3}(\mathrm{~A}=\mathrm{Al}, \mathrm{Sc}, \mathrm{Fe}$, and In). J. Phys. Chem. C 2014, 118, 4354-4361.

9. Blasse, G.; Bril, A. Crystal structure and fluorescence of some lanthanide gallium borates. J. Inorg. Nucl. Chem. 1967, 29, 266-267.

10. Dirksen, G.J.; Hoffman, A.; Vandebout, T.P.; Laudy, M.P.G.; Blasse, G. Luminescence spectra of pure and doped $\mathrm{GaBO}_{3}$ and $\mathrm{LiGaO}_{2}$. J. Mater. Chem. 1991, 1, 1001-1005.

11. Dotsenko, V.P.; Efryushina, N.P.; Berezovskaya, I.V. Luminescence properties of $\mathrm{GaBO}_{3}: \mathrm{Bi}^{3+}$ Mater. Lett. 1996, 28, 517-520.

12. Sajuti, D.; Yano, M.; Narushima, T.; Iguchi, Y. Phase diagrams of the $\mathrm{Ga}_{2} \mathrm{O}_{3}-\mathrm{B}_{2} \mathrm{O}_{3}$ and $\mathrm{In}_{2} \mathrm{O}_{3}-\mathrm{B}_{2} \mathrm{O}_{3}$ binary systems. Mater. Trans. JIM 1993, 34, 1195-1199.

13. Tajima, K.; Hino, Y.; Narushima, T.; Iguchi, Y. Activity of $\mathrm{Ga}_{2} \mathrm{O}_{3}$ in $\mathrm{B}_{2} \mathrm{O}_{3}$ flux and free energies of formation of $\mathrm{GaBO}_{3}$ and $\mathrm{InBO}_{3}$. Mater. Trans. JIM 2000, 41, 714-718.

14. Hoch, M. Thermodynamic properties and phase diagrams of the binary systems $\mathrm{B}_{2} \mathrm{O}_{3}-\mathrm{Ga}_{2} \mathrm{O}_{3}$, $\mathrm{B}_{2} \mathrm{O}_{3}-\mathrm{Al}_{2} \mathrm{O}_{3}$ and $\mathrm{B}_{2} \mathrm{O}_{3}-\mathrm{In}_{2} \mathrm{O}_{3}$. J. Alloys Compd. 2001, 320, 267-275.

15. Pelzer, H.; Muller, F. Thermochemistry of $\mathrm{GaBO}_{3}$ and phase equilibria in the $\mathrm{Ga}_{2} \mathrm{O}_{3}-\mathrm{B}_{2} \mathrm{O}_{3}$ system. J. Alloys Compd. 2001, 320, 262-266.

16. Bither, T.A.; Young, H.S. $\mathrm{MBO}_{3}$ Calcite-type borates of Al, Ga, Tl, and Rh. J. Solid State Chem. 1973, 6, 502-508.

17. Rudenko, V.V. High-temperature solution growth of $\mathrm{GaBO}_{3}$ crystals. Kristallografiya 1995, 40, 382-384.

18. Vitzthum, D.; Hering, S.A.; Perfler, L.; Huppertz, H. High-pressure syntheses and crystal structures of orthorhombic $\mathrm{DyGaO}_{3}$ and trigonal $\mathrm{GaBO}_{3}$ Z. Naturforschung Sect. B J. Chem. Sci. 2015, 70, 207-214. 
19. Levin, E.M.; Mc Daniel, C.L. The system $\mathrm{Bi}_{2} \mathrm{O}_{3}-\mathrm{B}_{2} \mathrm{O}_{3}$. J. Am. Ceram. Soc. 1962, 45, 355-360.

20. Sheldrick, G.M. A short history of SHELX. Acta Crystallogr. Sect. A 2008, 64, 112-122.

21. Farrugia, L.J. WinGX and ORTEP for Windows: An update. J. Appl. Crystallogr. 2012, 45, 849-854.

22. Spek, A.L. Structure validation in chemical crystallography. Acta Crystallogr. Sect. D Biol. Crystallogr. 2009, 65, 148-155.

(C) 2015 by the authors; licensee MDPI, Basel, Switzerland. This article is an open access article distributed under the terms and conditions of the Creative Commons Attribution license (http://creativecommons.org/licenses/by/4.0/). 